Article

\title{
Conceptual Pathways to Ethnic Transcendence in Diverse Churches: Theoretical Reflections on the Achievement of Successfully Integrated Congregations
}

\author{
Gerardo Marti \\ Department of Sociology, Box 7011, Davidson College, Davidson, NC 28035-7011, USA; \\ E-Mail: gemarti@davidson.edu; Tel.: +1-704-894-2000 \\ Academic Editor: Peter Iver Kaufman
}

Received: 18 June 2015 / Accepted: 17 August 2015 / Published: 2 September 2015

\begin{abstract}
The concept of ethnic transcendence-defined as the process of co-formulating a shared religious identity among diverse members that supersedes their racial and ethnic differences through congregational involvement — captures a critical aspect of successfully integrating different racial and ethnic groups into a single, commonly shared, multi-ethnic congregation. Drawing on classic theoretical resources from Max Weber and Emile Durkheim, this paper expands on previous scholarship by conceptually articulating two different paths for the achievement of ethnic transcendence in multiracial congregations. In the first path, ethnic transcendence supports and encourages congregational diversification by inspiring members and mobilizing them to contribute their efforts to accomplish a common religious mission. In the second path, the achievement of ethnic transcendence involves the sublimation of congregational members' religious selves to an overarching moral collective. Both paths involve privileging religious identities in favor of a particularistic ethnic or racial identity. Moreover, through both paths, the development of congregationally specific religious identities results in joining with co-members of different ethno-racial ancestries as a type of spiritually-derived kinship. Due to the fact that ethnic transcendence is an interactive process, congregational diversity is a bi-directional phenomenon representing the extent to which members allow for the integration of separate ethnicities/races into a common congregation through idealized and richly-symbolic notions of connection and belonging to a congregation. Overall, this paper suggests a heuristic framework that productively expands the concept of ethnic transcendence, allows an approach for observing cross-ethnic/inter-racial organizational processes, and ultimately contributes toward understanding how congregations (whether church, temple, or mosque)
\end{abstract}


pursue alternative identity reconstruction projects to sustain cohesive collective identities.

Keywords: race; ethnicity; congregations; diversity; multiethnic church; multiracial church; ethnic transcendence

\section{Introduction}

The core contribution of this paper is to provide conceptual resources for explaining the process by which diverse congregations (whether church, temple or mosque) become diversified. As more scholars enter this conversation, there remains a great deal of superficial discussion about the nature of diverse congregations. This is in part due to the definition of diverse congregations. Multiracial congregations are very simply defined as churches that have at least $20 \%$ of their membership being different from the majority population in terms of race or ethnicity [1,2]. That's it. In other words, to be categorized as "multiracial" a congregation only has to fulfill a particular demographic criterion: churches must have a composition of at least two races or ethnicities in regular attendance. Neither the specifics of the types of races or ethnicities matters, nor does the degree of diversification. Labeling churches multiethnic or multiracial does not tell us anything about a congregation other than it is not entirely homogeneous. However, ethnographic observation of multiple multiracial congregations in the United States leads me to suggest that diversity is far more than just a demographic snapshot of population proportions. Defining churches as "multiracial" places the focus on a seemingly static quality. Yet diversity-however it is defined - is never static. Diverse congregations summarize a complex set of social processes that successfully (and very rarely) bring segregated groups into an integrated space.

Productive scholarship should move beyond static definitions to explore dynamic processes. For example, multiracial congregations surely involve issues of power and authority, organizational values and rituals, migrations of people in and out of membership, understandings of race and religion that are negotiated and changed, interpersonal interactions that are both awkward and inspiring, and many other social mechanics involved in bringing people of different races and ethnicities together [3]. Scholarship attempts to uncover patterns and commonalities among these processes [4]. While multiracial congregations can be quite different and the diversity of diverse congregations will manifest different textures, this paper seeks to resource such work by conceptually isolating discernible processes that underlie the complexity of these churches and their racial compositions.

A prominent concept for understanding the process of achieving congregational diversity is ethnic transcendence [5-9]. The concept relies on acknowledging identity as consisting of multiple facets and behavioral repertoires, how saliency affects the accentuating or obscuring of different aspects of identity, and that congregations foster religious identities that assume primacy over particularistic ethnoracial affiliations. Similar research in multiracial Christian churches affirm that members' race-ethnicity can be displaced from in favor of a common religious identity within multiracial churches using the symbolic resources inherent to congregational structures [10-13]. An inclusive congregational identity, then, can be critical for the development of multiracial congregations, specifically, a religiously-grounded corporate identity has the potential to override the divisive aspects 
of members' racial/ethnic identity and allow the beneficial and energizing aspects of corporate belonging. While ethnic transcendence provides a broad sense of how congregational diversity is achieved, it is not a monolithic process, and the complexity with which religious identities become more salient than ethnoracial ones allows for multiple paths of understanding the accomplishment of diversity within congregations.

In short, the most challenging task in analyzing multiethnic/multiracial churches today is not to describe diversity but to explain it; more specifically, how do we explain how diverse multi-ethnic/multi-racial congregations become diverse and maintain that diversity over time? Multiracial congregations are not simply diverse, they become diverse (e.g., [14]). Even when congregations are founded as diverse churches, these churches cultivate, reproduce, and maintain a diverse membership over time. This implies social processes that are largely unexamined in the literature. To expand our theoretical considerations on the social processes inherent to the ongoing reproduction of multiracial congregations, I draw attention in this paper to the process of diversification through ethnic transcendence as encompassing two different paths. More specifically, drawing on Max Weber and Emile Durkheim, this paper presents two different paths of achieving ethnic transcendence - i.e., prioritizing relational affinity based on shared religious identity over an affinity based on similar racial or ethnic identities - resulting in a spiritual kinship. In the first path, ethnic transcendence supports congregational diversification by inspiring members and mobilizing them to contribute their efforts to accomplish a common religious mission. In the second path, ethnic transcendence involves the sublimation of congregational members' religious selves to an overarching moral collective. Both involve the privileging of religious identities in favor of a particularistic ethnic or racial identity. In both of these paths, religious identities are shaped within these congregations such that member involvement allows for the integration of separate ethnicities/races into a common congregation. In both paths, congregational diversity is a bi-directional phenomenon. Finally, both processes are presented as a heuristic for understanding how congregations pursue alternative identity reconstruction projects in creating cohesive congregations.

\section{Ethnic-Racial Identity, Congregational Practices, and Ethnic Transcendence}

Let's begin with what we already know. Racial and ethnic differences divide people. In our society, segregation by race and ethnicity is a well-established and persistent characteristic of social life [15-22]. These racial divisions are based in part on beliefs or ideas or constructs that create differences based on a presumption of physiological or other inheritable differences that are deemed to be natural and the institutional structures that channel and reinforce these beliefs. Fundamentally, segregation is based on an broad, underlying, and largely unquestioned ethos that defines different racial and ethnic groups as an "other" that keeps people from interacting in common settings or having common goals (e.g., [23-27]). Ideas in and of themselves are not determinant of social behavior (see [28]), yet widely-held and often pre-conscious judgments regarding race/ethnicity are significant—and not just because they consist of things that are held inside of our everyday notions of affinity and solidarity. Prejudicial ideas regarding race and ethnicity are persistently upheld because of structural arrangements that continue to keep races separated in American society. We know that beliefs/ideas/constructs related to race keep people separated and are reinforced through segregation and social settings, such as the housing market [20], 
the educational system [29,30], occupational structures [31] and religious assemblies [2,5]. Christian churches are the most segregated social institution in our society today, with less than $10 \%$ of all congregations having any significant degree of diversification. We know the religion has the potential of reinforcing the segregated ideas of race and ethnicity [2]. But we also know the religion has the capacity of reorienting those beliefs. In short, religion involves both ideas and structures. In focusing on understanding how religion is involved in the cultivation of multiracial congregations, it is important to conceptualize processes that account for both ideas and social interactions. Indeed, the motivation to understand multiracial congregations is in part an attempt to understand those moments when racial segregation is overcome and that perhaps by understanding multiracial congregations we have a promise of solving one of the most persistent social problems in America today [32].

To understand the ethnic identity of attenders in multiracial congregations, one cannot keep a static conception of identity. The conceptual resources for understanding congregational diversification presented here assumes the reality of "race" that appears in the minds of people despite its false biological base. In addition, the underlying theoretical framework views ethnicity as one of many multiple aspects of personal identity. I take as a theoretical commitment (described later in this paper) that personal identity is fluid and situated such that the different aspects of personal identity are highlighted or obscured depending in different interaction contexts and the strategic negotiation of individuals to particular bases of affinity. By acknowledging that individuals have multiple, overlapping, and even contradictory social locations, a person's social identity exists amidst a sense of relevance regarding aspects of their identity for social interactions. While I do not posit a strict identity hierarchy, the negotiation of identity involves understanding how different identities become salient in different contexts, which implies that situations invoke different identity hierarchies. In addition, this theoretical framework also acknowledges the role of organizational leaders as purposeful, reflective, conscious actors who help or hinder the process of diversification in their churches.

In order to understand the management negotiation and change of ethnic identity in multiracial congregations, a more fluid understanding of ethnicity is necessary [6], but a fluid understanding of identity goes against many popular notions of race and ethnicity, since everyday assumptions about ethnicity include that one is born with an ethnic identity, and that, like race, it is unchanging. Moreover, everyone in a racial/ethnic group presumably shares the same traits and customs. For example, the differing racial experience of African Americans relative to other racial groups in the United States makes the discussion of Black identity as situational and fluid a particular challenge; nevertheless, we know that African Americans, like other racial-ethnic groups, negotiate their racial identities in differing contexts [33,34]. Emerson [35] and Edwards [36] draw on racial formation and critical race theories and support that being Black in America is not simply one aspect of identity but rather overwhelms the identity of a person that religion largely fails to address. Yet, neither Emerson nor Edwards provide an explicit description of the process of religious racial integration through the ethnic affirmation which they believe is necessary for achieving truly integrated congregations; moreover, both argue that religious communities need to accentuate the distinctive racial experiences of African Americans and create hospitable environments that explicitly welcome and incorporate them (see also [37,38]). Furthermore, some identity malleability is noted in research focused on the African American experience in diverse congregations [8]. 
Many sociologists in the past have leaned toward a static definition by defining ethnicity as a social group distinguished by race, religion, language or national origin (e.g., [39,40]). Even if such uses of ethnicity are gross oversimplifications, they remain persistent. Now more recent series of ethnicity, including instrumental ethnicity, situational ethnicity social constructivist, and ethnic identity management theories severely criticize and radically amend the notions of "givenness" of ethnic identity [5,41-44]. In recognizing the fluidity of ethnic identity and the cultivation of diverse congregations, it is important to recognize insights from social constructivists, i.e., that one's ethnicity consists of a complex set of repertoires access to different times, according to different contexts. Social actors construct ethnic identities to suit different purposes since ethnic repertoires are learned in reconstructed for purposes of hand, using available symbolic resources (see [44-49]). Moreover, as "no one is a full-time ethnic" ([50], p. 95), ethnicity emerges as a "contingent, volitional, negotiated phenomenon, in which both societal circumstances and the creative assertions of human groups play veritable and interacting roles" ([51], p. 266). Ethnicity may become, for certain social actors in certain social contexts, a primary aspect of individual identity, while at other times ethnicity it is secondary. Certainly social actors have a limited number of ethnic categories to choose from, yet within these choices individuals choose whether to assert or obscure their ethnic identity. Following ethnic identity management theorists (see $[42,52,53]$ ), who extend insights from Goffman's impression management theory [54-56], ethnicity can be seen to have day-to-day or moment-by-moment variability in manifestation and salience. Following Goffman, impression management is a selective display of symbols of identity to maximize status within an interaction. Due to the fact that impression management is highly selective, displays of symbols of identity use available symbolic resources whether they be ethnic-specific or not. Social statuses other than ethnicity may be put forward instead to enhance social standing such that, as Okamura ([43], p. 460) states, "ethnicity may be of critical relevance in some situations, in others it may be totally irrelevant." This highlights a strategic element of human behavior; social actors use tactical maneuvers to manipulate their ethnic identity and conforming to expectations where needed and avoiding disruptions or embarrassment when not. Different audiences offer different performances [57].

By waiving static and deterministic conceptions of identity and embracing more recent notions, we move from a static to a dynamic accounting for racial/ethnic dynamics occurring in multiracial congregations. Ethnicity, then, is a complex aspect of the self with different aspects that can be highlighted or obscured, constructed or reconfigured, according to the demands and constraints of presentation since interests that involve social status and social mobility guide ethnic identity. Ethnic identity varies in importance of priority depending on the context of social actions, whether and how ethnic identity emerges is largely question of salience, and ethnic identity falls somewhere within a salience hierarchy in different situations (see [41]; also [58]). The salience of one's own ethnic self-presentation is situationally contingent, and its malleability is such that it is often obscured in favor of other aspects of self to maximize personal status. As circumstances require, other social status are emphasized in favor of ethnicity.

How ethnic and racial identities are negotiated and managed within diverse congregations is neither straightforward nor predetermined. Multiracial churches are complex in that every multiracial church achieves its diversity in different ways. Labeling a church as "multiethnic" or "multiracial" tells us almost nothing a congregation other than they are not homogeneous. Diversification is more than 
simply a demographic issue such that racial and ethnic affiliations occur through various paths; there is more to the stories embedded in particular multi-ethnic congregations that reveal a wealth of insight regarding the nature of churches, the nature of religious identities, and the nature of religious life at this point in history. Emerson and Kim [1] define types of multi-racial churches based on their sources of origin (e.g., sense of mission, consideration of congregational resources, mandated by higher authorities, etc.); these can serve as rough guides in "making sense" of the history of diversification in particular churches. Multiethnic/multiracial integrate at ethnic/racial groups but in different proportions. Even more, the label "multiracial" states that a church is characterized by racial diversity, but multiracial churches are, themselves, very diverse. If you look at two churches and characterize them as diverse, there may be few other things you can say that make these two churches the same. Minimally, multiracial churches describe congregations with members and attenders who have a common affiliation centered around common activity/ritual and/or common belief.

Further, the emergence of multiracial congregations cannot be adequately explained by the attitudes of individuals attending these congregations. Acknowledging the salience of micro-negotiations of identities within situations, an adequate grasp of diverse congregations demands that we consciously take into account organizational dynamics (see $[5,59,60]$ ). While it is possible that multiracial congregations attract already de-segregated people (meaning those with more open, tolerant and integrative attitudes, see [35]), explaining diverse congregations on the basis of attracting diversity-minded people overemphasizes individual attitudes and de-emphasizes structural dynamics that persistently keep people segregated in religious institutions. Evidence from contact theory and tested within religious organizations suggests that diverse congregations reduce prejudicial attitudes [32,61]. Yet evidence from racial analyses on institutionalized racism shows that "non-prejudiced" people overwhelmingly participate in segregated institutions, mostly by remaining consistent with white-dominant attitudes [36,62-65]. Furthermore, research on successfully diverse congregations demonstrate that individuals who join diverse congregations do not necessarily come for diversity but learn to engage in cross-racial/inter-ethnic relationships as a direct result of their engagements in their congregations. It was not their attitudes but the interactive processes upon entering the congregation that fostered a diverse congregational community [66]. Even more, while it is possible that congregations attract racially progressive individuals, recent research shows that diverse congregations consists of members who equally share white-dominant racial frames than racially progressive ones [67].

The overwhelming interest in racial reconciliation among church leaders demonstrates a belief in the possibility of diversifying congregations and that churches as organizations can be structured in order to overcome racial and ethnic bias [60]. Congregational leaders act on the belief that their churches can, with proper training and sensitivity, convert their congregations into places that are open, embracing and integrative [68]. Indeed evidence from Becker [10] in her own analysis of two multiracial churches shows how congregational leaders strategically use their theological resources to craft messages that inspire and provoke people toward actions and attitudes that encourage diversification. Such deliberate action on the part of congregational leaders successfully aids diversification $[5,38]$. To come to terms with the structural dynamics in the occurrence of attitude and behavioral changes within churches, a focus on congregations as organizational systems is necessary and therefore involves asking the question, what organizational processes within multiracial contributions account for diversification? 
In sum, this paper acknowledges that both individual personal identity negotiations and organizational practices contribute to the emergence of congregational diversification. More specifically, congregational diversification involves both individual processes of identity construction (by which I mean the formation and maintenance of a congregationally-specific religious identity) and organizational processes of cultural integration (by which I mean the attraction and acculturation of new and ethno-racially diverse members). I focus on the concept of "ethnic transcendence" as involving both of these processes of integration and identity to analytically highlight a set of social processes that account for the social processes inherent to different multiracial congregations.

\section{Conceptual Paths to Religious Racial Integration in Diverse Congregations}

This paper attempts to draw out underlying conceptual resources implicit to the working of "ethnic transcendence" as a core process of congregational diversification. While ethnic transcendence encompasses a set of dynamics, it is not assumed that ethnic transcendence is achieved in only one way, nor is it assumed that the processes presented here are exhaustive. Nevertheless, to briefly articulate two alternative paths of ethnic transcendence, I focus on theoretical resources found in the writings of Max Weber and Emile Durkheim. These two theorists are certainly not the only potential sources for approaching diversification. For example, Anthropologist Victor Turner ([69], p. 1342) described the "liminal state" in which participants, through participation in common ritual, set aside everyday roles and statuses. In the experience of liminality, participants shared humility before the sacred create a type of homogeneity and kinship. Reflecting on this process, Omar McRoberts ([70], p. 104) writes, "Victor Turner's communitas is a glimpse of radical equality-a vision that can be carried into the world of structures, statuses, and hierarchies to effect social transformation. Scholars of African American religion have followed suit, noting the communitas-generating, hierarchy-subverting potential of ecstatic worship." Applied to the workings of diverse congregations, multiracial churches find means to cultivate a common identity orientation on the basis of shared, even unspoken, religious affinities. Nevertheless, by focusing on Weber and Durkheim, I intend to achieve greater nuance in understanding how the religious identity fostered within a congregation is given greater priority and prominence over particularistic ethnic and regular identities.

The conceptual usefulness of Weber and Durkheim is that each one offers paths to diversity by highlighting how diverse congregations pursue (overtly) alternative organizational activities to integrate members that involve (covertly) alternative identity reconstruction projects. Diverse congregations use ritual and symbolic resources to cultivate moments of ethnic transcendence to religious identities in support their own goals/mission; these moments of ethnic transcendence reinforce the vitality of local congregations and the distinctive approach a community of congregants are to take on in the world. Drawing out potential connections between people on the basis of common aspirations, common interests or common life experiences is here viewed as the ongoing integrating task of leaders drawing people together in their religious assemblies [5,10]. In the first path, which draws on Weber, ethnic affiliations recede and a new, overriding, and mission-driven religious identity comes to the fore as charismatic leaders reorient individual identities toward a common sacred cause. The second path draws on Durkheim and emphasizes the corporate empowering of individuals through 
ritual worship as people of different racial affiliations perform powerful, new, and morally-binding social bonds in becoming part of a large, common, sacred tribe.

\section{Weber's Charismatic Authority: Renegotiating Identity around Common Interest in a Common Mission}

For Weber [71], charismatic leaders reorient the identity of followers, including their ethnic identity, toward a common cause. Stated differently, Weber asserts that ethnic identity is fluid and can be re-constructed around new interests. Thus, one path toward ethnic transcendence involves the effort of charismatic leaders to reorient identities of people and rouse them toward a common cause. This results in a re-construction of identity such that ethnic affiliations recede and a new overriding religious identity comes to the fore.

Max Weber's writings are useful yet under-recognized for articulating the dynamic nature of ethnic identity. Weber ([71], p. 389) defined ethnicity as rooted in a "belief in group affinity, regardless of whether it has any objective foundation", and ethnic groups as "those two groups have entertained subject to belief in their common dissent, because of similarities of physical type or of customs or both, or because of memories of colonization of migration." It is notions of racial/ethnic affinity that are important; actual objective kinship or bio-genetic relationships are not. For Weber ([71], p. 385), "race [and, by implication, ethnicity] creates a 'group' only when it is subjectively perceived as a common trait". In short, Weber anticipated more contemporary "constructivist" approaches to ethnicity by recognizing the subjectivity of ethnic affiliation and the social forces that contribute to the emergence and salience of ethnic bonds [43,44,46-49,51,72,73].

This means that the bases for ethnic group consolidation can and do shift. Weber suggests that the primary means by which ethnic groups emerge is out of mutual self-interest as a foundation for joint action. Interests - not biological lineage of vague ideas of shared culture-define the boundaries of ethnic groups. Further, Weber ([74], p. 189) also describes a moment when "a comprehensive societalization (focus on interests) integrates the ethnically divided communities into specific political and communal actions." In other words, when a concern emerges as relevant for the entire society (as in a time of war), ethnic distinctions are suspended and the entire society engages in communal action. Weber understood that people (and peoples) can and do alter their ethnic descriptions in the light of circumstances and environments that create common mutual interests. Weber's insight is affirmed by more recent ethnic theorists like Gleason ([75], p. 469) who states that "ethnicity is not an indelible stamp impressed on the psyche but a dimension of individual and group existence that can be consciously emphasized or deemphasized as a situation requires." Cornell ([51], p. 266) also affirms, "as circumstance or context changes, so does the calculus of ethnic identity claims and assignments, and likewise ethnic identity itself. Ethnicity becomes for the most part situational and determined by the product of more 'fundamental' forces." Since ethnicity has a fluid and durable significance as a personal organizing principle for priorities, loyalties, and relational connections, Weber and these more recent theorists assert that ethnic identity can be alternately reconstructed around new interests. So while theorists readily acknowledge ethnic groups can divide due to opposing interests, it is equally important to acknowledge that ethnic groups can also unite in pursuit of common interests. It is how these interests are defined as most critical. 
As an example, in churches like Mosaic in Los Angeles [5], common interests are re-defined around a cause-oriented mission, whether it is some form of social justice or the evangelistic thrust of reaching people with the gospel of Christ. These "missionary-entrepreneurs" have taken on a common cause defined and shaped by their congregations. Missionary-entrepreneurs are cultivated in dynamic, ongoing interactions with charismatic leaders from the pulpit and from involvement in multiple groups and projects in the activities of the congregation. Most significantly, the missionary-entrepreneur role readily fits into the bias toward individualism, relationalism (importance to interpersonal relationships), and anti-structuralism (inability/unwillingness to accept social structural influences), which Emerson and Smith ([2], pp. 69-92) describe as dominant among White evangelicals. People in White-dominant diverse churches center themselves within a Pan-Anglo culture, taking on a corporate charge to go into the world as an individual extension of the congregation. While this is not the only way in which the reorientation of ethnic identity toward common interest and mission can occur, Mosaic offers an extended and detailed empirical case in which diversity occurred by leaders using this explicit strategy to bring together multiple racial/ethnic groups (with some important caveats; see [5]). Mosaic uses several concrete practices to invoke and inspire toward a common religious mission, most notably through common confession of faith as a "follower of Christ", common rite of baptism by immersion, common public commitment to church membership, common meal in the Lord's Supper, and appeal to manifest a common character in attitudes and perspectives ([5], pp. 172-78). In addition to these specific rituals, Mosaic refers to theological claims regarding Christ's imperative to be "on mission" as well as placing great emphasis on developing warm one-on-one relationships in the congregation, especially through small group ministries.

In short, drawing on conceptual resources from Max Weber to delineate a first path toward congregational diversification, diversity can be accomplished to the cultivation of a missional thrust in a congregation that realigns personal identities toward distinctive religious interests that prioritize religious imperatives that trump ethnic and racial differences. This path toward ethnic transcendence involves the effort of charismatic leaders who reorient identities of people toward a common cause. This Weberian approach also acknowledges that all religious leaders must stake a claim to legitimacy, and in the cultivation of legitimacy, charismatic leaders access appropriate aspects of identity likely to enhance status toward achieving legitimacy.

A critical mechanism for exercise of their charismatic authority is through interpersonal engagement of ethnic impression management, since ethnicity is a potential roadblock to affinity [60,64]. Charismatic leaders acknowledge and negotiate (or manipulate) the presentation of their own ethnic identity. Various aspects of their own personal identities are assets, i.e., resources from which different repertoires of identity can be constructed. What is most important in the management of ethnic identity is to negotiate toward striking an affinity-some type of connection - that will allow the exercise of religious authority. This conceptual insight connects with Becker's [10] observation of two multiracial churches in which congregational leaders strategically used theological resources to craft messages to inspire and provoke people toward actions and attitudes that encourage ethno-racial diversification. Legitimated charismatic authority allows for working in the inner life of a congregant because charismatic leaders base their authority on value-rationality, a type of rationality that is a raised to a higher standard of ultimate values. It lifts people under charismatic authority from merely affectual relationships and overcomes merely instrumental bases of action. Yes, ethnic ties are deep and abiding, 
but value rationality can move people towards a higher calling, what Weber ([71], p. 30) defined as "a conscious belief in the value for its own sake of some ethical, aesthetic, religious, or other form of behavior, independently of its prospects for success". When charismatic leaders call on value-rationality, they call on an extraordinary source of motivation. Weber ([71], p. 25) continues, saying that "pure value rational orientation, would be the actions of persons who, regardless of possible cost of themselves, act to put into practice their convictions of what seems to them to be required by duty, honor, the pursuit of beauty, a religious call, personal loyalty, or the importance of some cause no matter in what it consists."

Leaders therefore consciously manage not only their own ethnic identity, but the ethnic identity of others. Ethnic identity is manipulated for value rational ends. In the context of building and maintaining a diverse congregation, this means that leaders use the complexity of ethnic identity to serve the value rational goals before them. Charismatic leaders manipulate their own ethnic identity as a tool. These charismatic leaders catalyze diverse groups for common mission that will supersede other group identities and highlight the new identity that fulfills a role toward completing the church's mission. Charismatic leaders construct a new religious identity and situations to be an inclusive identity that redefines relationships between people of different ethnicities. This new identity is created around the value-rational mission of the organization. In other words, by creating a new set of interests that supersede the divided communities inherent to different ethnic groups, individuals are catalyzed into a newly formed group characterized by common mission. This new group supersedes other group identities and serves to highlight the new identity that fulfills a role toward completing the church's mission. This results in a reconstruction of identity such that ethnic affiliations recede and a new, overriding religious identity becomes primary.

In sum, drawing on Weber, multiethnic congregations may be seen as products of a distinctive type of charismatic authority that changes the nature of ethnic identification. To accomplish this, value-rational, highly-idealized, and broadly encompassing purposes are emphasized in order to overcome ethnic specific affinities. This involves the renegotiation of ethnic identity and ethnic membership into a distinctive religious identity and religious membership. Ethnic identity becomes a resource utilized by leaders in multiethnic churches to maximize the goals of achieving organizational value rational ends. Ethnicity will be expressed if it serves instrumental ends. If ethnic identity is a resource, then ethnic identity is accentuated as a base of affinity, connection, and status. However, if ethnic identity is viewed as a roadblock, then ethnic identity is obscured in favor of other social status. The most important maneuver by charismatic leaders in cultivating diverse congregations is to build on a religiously based status honor to promote the vision of a community of people on mission with God together.

\section{Durkheim's Moral Community: Sublimating Oneself to a Collective Morality}

The sociological orientation of Emile Durkheim [76] in his grand and final work, Elementary Forms of Religious Life, emphasizes the collective empowering of individuals through corporate worship, meaning a communal gathering involving immersive, collective engagement toward a sacred and superior entity [77]. Pointing toward a more affective immersion of the individual into a collective social whole, the intense social interactions of corporate worship involves a process of identity 
absorption to a collectively-oriented, transcendent divinity that simultaneously happens alongside a process of dynamic bonding between individuals. Together, those gathered in the intense space of corporate worship experience a shared sense of empowerment, one that uniquely energizes participants in ways that cannot happen outside of such an occasion. Durkheim therefore argues that as individuals participate in a corporate orientation to the sacred, which constitutes a (re)construction of their religious identity through the abandonment of one's (isolated and individual) self to the collective experience of worship. In doing so, members sublimate themselves to a shared authority, one that is not strictly personal to a leader but personalized in those who carry authoritative roles, under a common orientation to worship of a transcendent god or supernatural forces.

Durkheim ([76], p. 44) defined religion as "a unified system of beliefs and practices relative to sacred things." The phrase "beliefs and practices" is intended to accentuate that religion is not merely assent to doctrines, nor is it merely routinized engagement in structured activities; the full scope of Durkheim's work encourages seeing religion as a fully conscious and deeply engaged form of social bonding. In Book Three of The Elementary Forms of Religious Life, he analytically describes rituals of integration that bring together sacred people that connect otherwise isolated individuals (see [78], pp. 17-19). For Durkheim ([76], p. 352), all people need such connections because we ordinarily experience everyday life as a "day-in, day-out struggle" full of "incessant conflict and friction." Coming together through energizing ritual action "refreshes a spirit worn down by all that is overburdening in day-to-day labor" ([76], p. 385). Through corporate worship, the "individual soul" is "regenerated by immersing itself once more in the very wellspring of its life. As a result, that soul is stronger" ([76], p.353). The result of corporate worship is the empowerment of spiritually connected "kin" such that congregants of disparate ethnic and racial affiliations draw together as part of a large, common, sacred tribe.

Durkheim's arguments regarding the revitalizing effects of corporate worship are among the most compelling aspects of his famous analysis. He persuasively argues that corporate worship provides a unique source of inspiration for individuals enabling them to live out their day-to-day lives. As Durkheim states, after participating in a corporate orientation to the sacred, "we return to profane life with more energy and enthusiasm, not only because we have placed ourselves in contact with a higher source of energy but also because our own capacities have been replenished through living, for a few moments, a life that is less tense, more at ease, and freer" ([76], p. 386). Durkheim ([76], p. 419) is emphatic on the need for such corporate social immersion, stating, "The believer who has communed with his god is not simply a man who sees new truths that the unbeliever knows not; he is a man who is stronger. Within himself, he feels more strength to endure the trials of existence or to overcome them." Essentially, a Durkheimian process of absorption through worship in a transcendent divinity as part of a large, common, sacred tribe allows individuals to carry out the mundane and wearing routines of everyday work and life. As Jones ([79], p. 41) notes, a critical aspect of religion for Durkheim is its "dynamogenic" quality that constitutes a "capacity to give rise to actions as well as thoughts, to enable the believer to transcend his merely individual powers, to become capable of greater things."

Following Durkheim, the revitalizing experience of corporate empowerment is potentially significant for diverse churches that follow this path of nurturing empowered achievers. The power of worship for nurturing integration among different racial/ethnic groups has been noted elsewhere $[37,38,59,63,80]$. Durkheim further specifies how worshippers abandon themselves to a 
participation in the divine and experience empowerment and that these connections and subsequent empowerment are reinforced in the practical, encouraging teaching and preaching designed to coach achievers as they walk through life. Members know challenges and struggles that exist in their world. They have found it difficult, even impossible, to measure up to societal standards or experience a sense of achievement or success. They are aware of their errors and mistakes. Yet religious communities provide moral identities that anchors difficult career choices and failed opportunities. Teachings may emphasize God's care for people if they continue to do what is right. Connecting with others through worship to reenergize oneself involves a re-construction of identity through the abandonment of self to worship and the experience of empowerment. A moral community is crafted through corporate worship that abides within the person and guides their behavior - even when the congregation is dispersed.

A core concern for Durkheim in all of this theoretical work is the need to provide people a cohesive moral order within themselves that sustains them in the midst of a complex society where individuals participate in multiple locations. Durkheim's theoretical problem (how do disconnected individuals continually guide themselves by collective moral standards?) is a practical problem for all congregational leaders who seek to build a morally cohesive community in densely populated, metropolitan settings and whose members come from widely differing social backgrounds. Congregational leaders (whether pastor, priest, rabbi, or imam) seek to cultivate a public morality, i.e., a set of standards and how to conduct oneself in the world. For Durkheim [81], morality and discipline are interconnected. Cultivating morality requires socially fostering a base of personal discipline that keeps people from egoistically acting out their own desires without regard for the concerns of others or for the society as a whole. Morality, although experienced to something that is external and coming outside of us, guides and structures our actions internally in a way that allows us to watch out for other people [81]. It involves a public concern for other people.

The centrality of worship and the cultivation of an abiding moral community is particularly characteristic of Oasis Christian Center in Los Angeles [59,82]. At Oasis Christian Center, high-quality, energizing, foot-stomping, body-swaying, hand-raising worship at the church encourages spirit-filled believers to accomplish great things in the world. Members at Oasis are immersed in the ego-centric world of the Hollywood entertainment industry where self-promotion is key; yet, their church moves them to subsume their personal ambitions to idealized spiritual ones as represented in their church. Oasis urges members to take responsibility over their lives as an extension of their stewardship to God. The religious identity provided through participation at Oasis radically binds people into a deep sense of solidarity with other struggling Christians who are trying to make it in a difficult world where careers are haphazard, relationships are full of distrust, and utter selfishness is rampant. To be in the worship service at Oasis is to stand, clap, sway, and smile as audience and performers lose themselves in the service. One young white musician said, "I felt God's presence working in my life to get me in the church and to get me working for the kingdom." Another member said, "I had to learn how to worship, and the way I had to learn how to worship is to just let go, to let go. To let go and let God." Through participating in a corporate orientation to the sacred, members abandon themselves to worship. Indeed, the key to good worship is to lose self-consciousness [82]. Members immerse themselves in the immediacy of worship; yet, beyond the excitement of energized gatherings, members of Oasis take on an institutionalized role that persists even beyond their formal participation in the congregation. The stable organizational structure of congregations provides a 
viable, persistent base for maintaining a shared, religiously-oriented corporate identity, allowing individuals to negotiate the many ambiguous and complex demands of modern everyday life. Overall, members at Oasis affirm a personal orientation of "homelessness" in the world alongside familial bonding in the church; participate in highly engaging and emotional worship services; and accept intimate life direction from pastoral "coaches" to inform moral choices for life decisions that include clothing choices, dating partners, and career moves (see [59]).

In sum, Durkheim's theorizing on how human identity emerges in the context of a group, and his conviction that the self cannot exist outside of the collectivity, suggests that diverse congregations constitute a distinctive moral community in which egoism is not to prevail. Congregations are places full of relationships that are not based so much on common interests but on a common affectual connection to the sacred where religious identities are reinforced through community structures that provide moral sensitivities to orient and guide them in day-to-day life. Participating in congregational life forges intimate social bonds, and these relational connections become the source of type of spiritual "familial" life. As a family, they experience loyalty, duty, and obligation to do those things that would reflect best on their congregational family. Indeed, among congregants interviewed in past research $[5,59,60]$, their multiracial congregation was the most or best "family" they ever experienced. They put aside particularistic concerns in favor of collective concerns that reflect their energizing, morally-binding collective community.

\section{Conclusions}

Religious congregations, like any other organization, define places of inclusion and exclusion. Racially and ethnically churches are particularly interesting as places of inclusion due to the complexity of forging cross-ethnic/inter-racial relationships. Theoretical concepts provide imaginative tools for heuristically understanding the processes by which diverse congregations develop, processes which are especially important to grasp as the mere label of "multi-ethnic" or "multi-racial" tells us almost nothing about a congregation other than they are not homogeneous. Overall, the discussion focuses on further articulating pathways for the accomplishment of ethnic transcendence, by which is meant different conceptual understandings for the achievement of alternative identity reorientation projects. More specifically, this paper emphasizes that differences in ethnic/racial integration within congregations occur because diversification is achieved through alternative "paths" cultivated by spiritual leaders through the ongoing rituals that create and reinforce them within their congregations. These paths pursue (overtly) alternative religious activities that involve (covertly) alternative identity reconstruction projects. The first path draws on Max Weber and describes the effort of charismatic leaders who reorient individual identities toward a common, sacred cause. Ethnic affiliations recede while a new overriding, mission-driven religious identity comes to the fore. The second path draws on Emile Durkheim and emphasizes the corporate empowering and consequent absorption of individuals into a moral community through ritual worship. Members who come from disparate racial and ethnic affiliations form powerful, new, and family-like bonds as part of a large, common, sacred tribe.

In short, regardless of the pathways by which it is achieved, the success of diverse congregations lies in the ability to subsume their member's ethnic/racial identities in favor of a shared congregational bond. Because these paths focus on organizational processes, this discussion lacks considerations of 
the broad demographic environment that may be needed to be able to have any degree of ethnic or racial diversity. It also ignores that there may be distinctive forms of leadership that promote diversification as well as the possibility that characteristics of individuals who may be more open or more likely to join diverse churches. Instead, the main emphasis here is to assert that congregational diversity is more than simply a demographic "snapshot" of population proportions. Diversity within any congregation is the result of cumulative processes that occur among social actors over a period of time. The conceptual foci proposed here draw attention to the influence of organizational processes, in particular, a focus on alternative identity reorientation projects as a way to explain how the relationship between racial/ethnic and religious identities may be aligned to allow for religious racial/ethnic integration to occur. Diverse congregations are invoking different identity hierarchies.

This is not to argue that multiethnic congregational experiences actually "change" the substance of ethnic/racial identity but rather that it may push-off the centrality of racial and ethnic affiliation to the wayside in these religious contexts. Yet, here it is important to note that within a diverse congregation one's ethnic/racial identity may not necessarily run counter to a newly formed religious identity found. Essentially, it is possible that a multiracial congregation can be a mechanism for reinforcing one's prior ethnic/racial identity since the goals of an ethnic community may be fully consonant with and supported by those of the congregation. People may therefore be motivated to participate in a multiracial congregation and feel a sense of connection and belonging because the goals and strategies of that community forward their ethnicity-specific goals and strategies. Within the Weberian model, a person's commitment to his or her own ethno-racial identity-and its related value to, perhaps, "justice" - could be reinforced (rather than superseded) by a multiracial congregation's missional commitment to racial justice as intended by God. Alternatively, within the Durkheimian model, a person's understanding of his or her own ethno-racial identity may be tied to a particular form of ecstatic worship (e.g., "This is how we, as [insert ethnicity], worship") and therefore find their ethno-racial identity affirmed (rather than superseded) by participation in the worship practices of a particular congregation. Thus, the common religious identity forged within a diverse congregation may reinforce rather than subvert or obscure one's ethno-racial identity.

Also, it is indeed possible that ethnic transcendence is provisional and contingent. While this article strives to conceptually account for the achievement of religious racial integration in diverse congregations, scholars have many unanswered questions regarding the extent of its effects on members. Do congregations attract non-segregated members? Are members more progressive in their racial attitudes? Do members succeeding at ethnic transcendence thereby become more racially open and tolerant in their lives beyond the congregation? Or is it possible that members from differing racial and ethnic groups who join diverse congregations actually share similar racial attitudes such that the congregation affirms rather than changes them (see [67])? While these questions lie beyond the scope of this article, greater research is required to establish the connections between participation in diverse congregations and the broader effects on the ethno-racial identity and cross-racial interactions beyond the congregation.

Finally, while much of the cited research on diverse congregations is based in Christianity (and there are many well-known American churches with diverse membership, including Glide Methodist Church in San Francisco and Riverside Church in New York), the pathways described here are intended to be applicable across religious orientations, and some of this scholarship is already being 
accomplished (among the Baha'i, see [83]; among American Muslims, see [84]). Hopefully, this paper will urge even further research on diverse congregations in other faith traditions (see [9]).

\section{Conflicts of Interest}

The author declares no conflict of interest.

\section{References}

1. Emerson, Michael O., and Karen Chai Kim. "Multiracial Congregations: An Analysis of Their Development and a Typology." Journal for the Scientific Study of Religion 42 (2003): 217-27.

2. Emerson, Michael O., and Christian Smith. Divided by Faith: Evangelicals and the Problem of Race in America. New York: Oxford University Press, 2000.

3. Yancey, George, and Michael O. Emerson. "Integrated Sundays: An Exploratory Study into the Formation of Multiracial Churches." Sociological Focus 36 (2003): 111-27.

4. Edwards, Korie L., Brad Christerson, and Michael O. Emerson. "Race, Religious Organizations, and Integration.” Annual Review of Sociology 39 (2013): 311-28.

5. Marti, Gerardo. A Mosaic of Believers: Diversity and Innovation in a Multiethnic Church. Bloomington: Indiana University Press, 2005.

6. Marti, Gerardo. "Fluid Ethnicity and Ethnic Transcendence." Journal for the Scientific Study of Religion 47 (2008): 11-16.

7. Marti, Gerardo. "Affinity, Identity, and Transcendence: The Experience of Religious Racial Integration in Multiracial Churches." Journal for the Scientific Study of Religion 48 (2009): $53-68$.

8. Marti, Gerardo. "The Religious Racial Integration of African Americans into Diverse Churches." Journal for the Scientific Study of Religion 49 (2010): 201-17.

9. Marti, Gerardo. "When Does Religious Racial Integration 'Count'? A Caution about Seeking Ideal Ethnographic Cases.” Journal for the Scientific Study of Religion 49 (2010): 291-98.

10. Becker, Penny Edgell. "Making Inclusive Communities: Congregations and the 'Problem' of Race." Social Problems 45 (1998): 451-72.

11. Ecklund, Elaine Howard. Korean American Evangelicals: New Models for Civic Life. New York: Oxford University Press, 2006.

12. Garces-Foley, Kathleen. Crossing the Ethnic Divide: The Multiethnic Church on a Mission. New York: Oxford University Press, 2007.

13. Stanczak, Gregory C. "Strategic ethnicity: The construction of multi-racial/multi-ethnic religious community." Ethnic and Racial Studies 29 (2006): 856-81.

14. Dougherty, Kevin D., Gerardo Marti, and Brandon Martinez. "Congregational Diversity and Attendance in a Mainline Protestant Denomination." Journal for the Scientific Study of Religion, forthcoming.

15. Blalock, Herbert M. "Percent Non-White and Discrimination in the South." American Sociological Review 22 (1957): 667-82. 
16. Blanchard, Troy C. "Conservative Protestant Congregations and Racial Residential Segregation: Evaluating the Closed Community Thesis in Metropolitan and Nonmetropolitan Counties." American Sociological Review 72 (2007): 416-33.

17. Brown, Prince, Jr. "Biology and the Social Construction of the 'Race' Concept." In The Social Construction of Race and Ethnicity in the United States, 2nd ed. Edited by Robert Ferrante and Prince Brown, Jr. Upper Saddle River: Prentice Hall, 2001, pp. 144-50.

18. Goldberg, David Theo. Racist Culture: Philosophy and the Politics of Meaning. Malden: Blackwell, 1993.

19. Massey, Douglas S., and Nancy A. Denton. "The Dimensions of Racial Segregation." Social Forces 67 (1988): 281-315.

20. Massey, Douglas S., and Nancy A. Denton. American Apartheid: Segregation and the Making of the Underclass. Cambridge: Harvard University Press, 1993.

21. Massey, Douglas S., and Andrew B. Gross. "Explaining Trends in Racial Segregation, 1970-1980.” Urban Affairs Quarterly 27 (1991): 13-35.

22. Brown, Michael K., Martin Carnoy, Elliott Currie, Troy Duster, David B. Oppenheimer, Marjorie M. Schultz, and David Wellman. Whitewashing Race: The Myth of a Colour-Blind Society. Berkeley: University of California Press, 2003.

23. Bailey, Benjamin. "Dominican-American Ethnic/Racial Identities and United States Social Categories." International Migration Review 35 (2001): 677-708.

24. Itzigsohn, Jose, and Carlos Dore-Cabral. "Competing identities? Race, ethnicity and panethnicity among Dominicans in the United States." Sociological Forum 15 (2000): 225-47.

25. Newby, Alison, and Julie Dowling. "Black and Hispanic: The Racial Identification of Afro-Cuban Immigrants in the Southwest." Sociological Perspectives 50 (2007): 343-66.

26. Padilla, Felix. Latino Ethnic Consciousness: The Case of Mexican Americans and Puerto Ricans in Chicago. Notre Dame: University of Notre Dame Press, 1985.

27. Saillant, Silvio T. "The Tribulations of Blackness: Stages in Dominican Racial Identity." Latin American Perspectives 25 (1998): 126-46.

28. Emirbayer, Mustafa, and Ann Mische. "What Is Agency?" American Journal of Sociology 103 (1998): 962-1023.

29. Lewis, Amanda E. Race in the Schoolyard: Negotiating the Color Line in Classrooms and Communities. New Brunswick: Rutgers University Press, 2003.

30. Tatum, Beverly Daniel. Why Are All the Black Kids Sitting Together in the Cafeteria? And Other Conversations about Race. New York: Basic Books, 2003.

31. Royster, Deirdre A. Race and the Invisible Hand: How White Networks Exclude Black Men from Blue Collar Jobs. Berkeley: University of California Press, 2003.

32. Yancey, George. "An Examination of the Effects of Residential and Church Integration on Racial Attitudes of whites.” Sociological Perspectives 42 (1999): 279-305.

33. Hutchinson, Janis Faye, Nestor Rodriguez, and Jacqueline Hagan. "Community Life: African Americans in Multiethnic Residential Areas.” Journal of Black Studies 27 (1996): 201-23.

34. Young, Vershawn Ashanti. Your Average Nigga: Performing Race, Literacy, and Masculinity. Detroit: Wayne State, 2007. 
35. Emerson, Michael O. People of the Dream: Multiracial Congregations in the United States. Princeton: Princeton University Press, 2006.

36. Edwards, Korie L. The Elusive Dream: The Power of Race in Interracial Churches. New York: Oxford University Press, 2008.

37. DeYoung, Curtiss Paul, Michael O. Emerson, George Yancey, and Karen Chai. United by Faith: Multicultural Congregations as a Response to the Problem of Race. New York: Oxford University Press, 2003.

38. Yancey, George. One Body, One Spirit: Principles of Successful Multiracial Churches. Downers Grove: InterVarsity Press, 2003.

39. Gordon, Milton M. Assimilation in American Life: The Role of Race, Religion and National Origins. New York: Oxford University Press, 1964.

40. Schermerhorn, Richard A. Comparative Ethnic Relations. New York: Random House, 1970.

41. Nagata, Judith A. "What is a Malay? Situational Selection of Ethnic Identity in a Plural Society." American Ethnologist 1 (1974): 331-50.

42. Lyman, Stanford M., and William A. Douglas. "Ethnicity: Strategies of Collective and Individual Impression Management." Social Research 40 (1973): 344-65.

43. Okamura, Jonathan Y. "Situational ethnicity." Ethnic and Racial Studies 4 (1981): 452-65.

44. Royce, Anya Peterson. Ethnic Identity: Strategies of Diversity. Bloomington: Indiana University Press, 1982.

45. Alexander, Claire E. The Art of Being Black: The Creation of Black British Youth Identities. New York: Oxford University Press, 1996.

46. Conzen, Kathleen N., David A. Gerber, Eva Morawska, George E. Pozzetta, and Rudolph J. Vecolli. "The Invention of Ethnicity: A Perspective from the USA." Journal of American Ethnic History 12 (1992): 3-41.

47. Leonard, Karen Isaksen. Making Ethnic Choices: California's Punjabi Mexican Americans. Philadelphia: Temple University Press, 1992.

48. Nagel, Joane. American Indian Ethnic Renewal: Red Power and the Resurgence of Identity and Culture. New York: Oxford University Press, 1996.

49. Sollors, Werner, ed. The Invention of Ethnicity. New York: Oxford University Press, 1989.

50. Fenton, Steve. Ethnicity: Racism, Class, Culture. New York: Rowman \& Littlefield Publishers, Inc., 1999.

51. Cornell, Stephen. "The Variable Ties that Bind: Content and Circumstances in Ethnic Processes." Ethnic and Racial Studies 19 (1996): 265-89.

52. De Vos, George. "Ethnic Pluralism: Conflict and Accommodation." In Ethnic Identity: Cultural Continuities and Change. Edited by George A. De Vos and Lola Romanucci-Ross. Palo Alto: Mayfield Publishing, 1975, pp. 5-41.

53. De Vos, George, and Lola Romaucci-Ross. "Ethnicity: Vessel of Meaning and Emblem of Contrast." In Ethnic Identity: Cultural Continuities and Change. Edited by George A. De Vos and Lola Romanucci-Ross. Palo Alto: Mayfield Publishing, 1975, pp. 363-90.

54. Goffman, Erving. The Presentation of Self in Everyday Life. Garden City: Doubleday, 1959.

55. Goffman, Erving. Behavior in Public Places: Notes on the Social Organization of Gatherings. New York: Free Press of Glencoe, 1963. 
56. Goffman, Erving. Interaction Ritual: Essays in Face-to-Face Behavior. Chicago: Aldine Publishing, 1967.

57. Baumann, Gerd. The Multicultural Riddle: Rethinking National, Ethnic, and Religious Identities. New York: Routledge, 1999.

58. Stryker, Sheldon. "Symbolic Interactionism: Themes and Variations." In Social Psychology: Sociological Perspectives. Edited by Morris Rosenberg and Ralph H. Turner. New York: Basic Books, 1982, pp. 3-29.

59. Marti, Gerardo. Hollywood Faith: Holiness, Prosperity, and Ambition in a Los Angeles Church. New Brunswick: Rutgers University Press, 2008.

60. Marti, Gerardo. Worship across the Racial Divide: Religious Music and the Multiracial Congregation. New York and London: Oxford University Press, 2012.

61. Yancey, George. "Racial Attitudes: Differences in Racial Attitudes of People Attending Multiracial and Uniracial Congregations." Research in the Social Scientific Study of Religion 12 (2001): 185-206.

62. Bonilla-Silva, Eduardo. Racism without Racists: Color-Blind Racism and the Persistence of Racial Inequality in America. New York: Rowman and Littlefield, 2009.

63. Christerson, Brad, Korie L. Edwards, and Michael O. Emerson. Against All Odds: The Struggle for Racial Integration in Religious Organizations. New York: New York University Press, 2005.

64. Edwards, Korie L. "Role Strain Theory and Understanding the Role of Head Clergy in Racially Diverse Churches." Sociology of Religion 75 (2014): 57-79.

65. Feagin, Joe. Racist America: Roots, Current Realities, and Future Reparations. New York: Routledge, 2001.

66. Marti, Gerardo. "The Diversity Affirming Latino: Ethnic Options and the Ethnic Transcendent Expression of American Latino Religious Identity." In Sustaining Faith Traditions: Race, Ethnicity, and Religion among the Latino and Asian American Second Generation. Edited by Carolyn E. Chen and Russell E. Jeung. New York: New York University Press, 2012, pp. 25-45.

67. Cobb, Ryon J., Samuel L. Perry, and Kevin D. Dougherty. "United by Faith? Race/Ethnicity, Congregational Diversity, and Explanations of Racial Inequality." Sociology of Religion 76 (2015): 177-98.

68. Marti, Gerardo, and Michael Emerson. "The Rise of the Diversity Expert: How American Evangelicals Simultaneously Accentuate and Ignore Race." In The New Evangelical Social Engagement. Edited by Brian Steensland and Philip K. Goff. New York: Oxford University Press, 2013, pp. 179-99.

69. Turner, Victor. Dramas, Fields, and Metaphors: Symbolic Action in Human Society. Ithaca and London: Cornell University Press, 1974.

70. McRoberts, Omar M. Streets of Glory: Church and Community in a Black Urban Neighborhood. Chicago: University of Chicago, 2003.

71. Weber, Max. Economy and Society: An Outline of Interpretive Sociology. Berkeley: University of California Press, 1978.

72. McKay, James. "An Exploratory Synthesis of Primordial and Mobilisationist Approaches to Ethnic Phenomena." Ethnic and Racial Studies 5 (1982): 395-420. 
73. Roosens, Eugeen. Creating Ethnicity: The Process of Ethnogenesis: Frontiers of Anthropology. Newbury Park: Sage, 1989, vol. 5.

74. Weber, Max. "Class, Status, Party.” In From Max Weber: Essays in Sociology. Edited and translated by Hans Heinrich Gerth and C. Wright Mills. New York: Oxford University Press, 1946, pp. 180-95.

75. Gleason, Philip. "Identifying Identity: A Semantic History.” The Journal of American History 69 (1983): 910-31.

76. Durkheim, Emile. The Elementary Forms of Religious Life. Translated by Karen E. Fields. New York: The Free Press, 1995.

77. Jones, Robert Alun. The Development of Durkheim's Social Realism. New York: Cambridge University Press, 1999.

78. Jay, Nancy. Throughout Your Generations Forever: Sacrifice, Religion and Paternity. Chicago: University of Chicago Press, 1992.

79. Jones, Robert Alun. "Religion and Science in the Elementary Forms." In On Durkheim's Elementary Forms of Religious Life. Edited by N. J. Allen, W. S. F. Pickering and W. Watts Miller. London: Routledge, 1998, pp. 39-52.

80. Dougherty, Kevin D., and Kimberly R. Huyser. "Racially Diverse Congregations: Organizational Identity and the Accommodation of Differences." Journal for the Scientific Study of Religion 47 (2008): 23-43.

81. Durkheim, Emile. Moral Education: A Study in the Theory and Application of the Sociology of Education. New York: Free Press of Glencoe, 1961.

82. Marti, Gerardo. "Ego-affirming Evangelicalism: How a Hollywood Church Appropriates Religion for Workers in the Creative Class." Sociology of Religion 71 (2010): 52-75.

83. McMullen, Michael. The Baha'i: The Religious Construction of a Global Identity. New Brunswick: Rutgers University Press, 2000.

84. Sheikh, Christine Soriea. The American Ummah: Identity and Adaptation among Second-Generation Muslim Americans. New Brunswick: Rutgers University Press, forthcoming.

(C) 2015 by the author; licensee MDPI, Basel, Switzerland. This article is an open access article distributed under the terms and conditions of the Creative Commons Attribution license (http://Creativecommons.org/licenses/by/4.0/). 